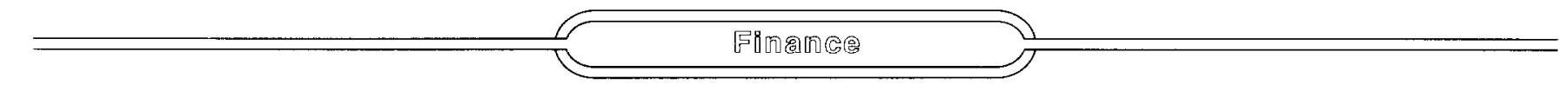

\title{
Pure Price Changes of Lodging Properties
}

\section{Establishing comparable prices of lodging properties has been difficult due to differences in size, location, and market, but now there's a tool to help both buyers and sellers figure a fair deal*}

\section{by John B. Corgel and Jan A. deRoos}

NEVER BEFORE has there been so much interest in the data and the methodology for measuring the financial performance of incomeproducing real estate. Yet, the development of accurate performance measures progresses slowly. A particular property is infrequently traded and comparing different properties is impractical because of the unique characteristics of each property. These problems led one observer to comment:

John B. Corgel is associate professor and Jan A. deRoos is assistant professor at the Cornell University School of Hotel Administration, where Annika Farrell provided research assistance for this study. The authors extend their sincere appreciation to Stephen Rushmore and Daniel Lesser of Hospitality Valuation Services and to the members of the Hotel Motel Brokers Association for their cooperation in assembling the data for this study. This study could not have been completed without the financial support of the Cornell University School of Hotel Administration.

Compared with the electric worlds of stocks and bonds, real estate is in the investment dark ages. Even at the end of the year, no one knows for sure whether prices are up or down. ${ }^{1}$

The inability to measure accurately the performance of classes of properties, such as hotels and motels, may lead to inefficient allocations of capital to develop-

*Ed. note: Readers who are not concerned with the issues surrounding the index's development may wish to skip directly to the results, on page 75 .

${ }^{1} R$. Lowenstein, "The S\&P Guide to Real Estate Investing: Index, Index, Index," The Wall Street Journal, November 8, 1988, p. C1.

(c) 1992, Cornell University. 
ment, equity investment, and debt financing of such property types. Also, hospitality-corporation strategies such as acquisitions, divestitures, sale and "leasebacks," and sale and "managebacks" are most successful when owners and managers can track the historical price movements of real estate.

In this article, we report on research to measure the temporal changes in the prices of lodging properties. Our specific objective is to present the results of an ongoing study at the Cornell University School of Hotel Administration to model and index the selling prices of lodging properties. The Cornellindex study reveals that prices responded quickly to changes in the tax treatment of real estate contained in the 1986 Tax Reform Act, and those prices have remained below 1985 levels ever since-this despite well-publicized Japanese investment in U.S. real estate.

\section{Who Uses Price Indexes?}

Indexes of lodging real-estate prices may appeal to a broad spectrum of hospitality firms, investors, mortgage underwriters, and appraisers in their evaluations of trends in lodging real estate and of specific hotel or motel properties. For example, the hospitality industry has undergone fundamental changes in the way real estate is controlled for business operations. Although some firms increased the percentage of properties owned during the past ten years (e.g., Westin Hotels), many divested their real estate, often through sale and manageback contracts. Future decisions by hospitality-firm executives to acquire, hold, or divest real estate will depend on their knowledge of past price trends as indicators of future appreciation.

Equity investors are now approaching real-estate markets with considerable caution and discipline and, as a result, reliable sources of information are in greater demand by investors. The substantial growth in real-estate investment over the past decade means that more real estate is held than ever before in anticipation of appreciation and eventual sale. ${ }^{2}$

Just as investors have become cautious in real-estate deals, lenders are imposing strict underwriting standards. For them, wellconstructed price indexes serve as an important source of information for evaluating the collateral supporting mortgage loans on lodging properties and other income-producing real estate.

The hedonic pricing methods that underlie the price indexes presented in this article introduce a strong element of objectivity into the appraisal process. This is because they are transaction-based approaches to financial performance, in which the effects on price of many property-related characteristics may be examined simultaneously and can serve as a check against other, traditional methods.

Appraisers learn about the factors affecting value and the reliability of income-capitalization approaches from hedonic-pricing research and, therefore, appraisers may be guided toward better estimates of market value.

\section{Real-Estate Prices: Difficult to Index}

A price index is a statistical device for measuring differences between groups of price data, usually at different points in time. Several popular price indexes, such as the Consumer Price Index, rely on measures of central tendency, such as average and median prices, between controlled groups of data. Such measures are adequate to

\footnotetext{
See Stephen E. Roulac and Neil F. Dimick, "Real Estate Capital Markets Undergo

Fundamental Changes," The Real Estate Finance Journal, 6, No. 3 (Winter 1991), p. 8.
}

represent the temporal changes in prices of goods and services traded in common units and in active markets. These price indexes are also useful for goods and services for which the quality remains fairly constant over time.

Real estate is ill-suited for performance measurement using central-tendency indexes of observed prices. Properties trade infrequently and transaction prices are therefore not as plentiful as they are with regard to other markets (stocks, for cxample, or automobiles). Besides, the set of properties sold during successive periods may be quite dissimilar in size, location, and other attributes.

Another problem is that real estate is not homogeneous. Each property's performance is affected by a unique set of geographic factors and market conditions that must be statistically controlled. Finally, the quality of any given property or class of properties changes with time. For example, "VIP Floors" in hotels were not featured ten years ago, but today they are found in many properties catering to business travelers. ${ }^{3}$

A comprehensive indexing procedure for lodging-property sale prices must overcome the following four factors that make real-estate transactions difficult to compare:

(1) Heterogeneous sales (i.e., different properties selling in successive periods);

(2) Quantity (i.e., different numbers of properties or rooms selling in successive periods);

(3) Quality (i.e., physical features and service levels of properties changing over time); and

(4) Extraordinary events (i.e., local economic events that affect some transactions but not others).

\footnotetext{
${ }^{3}$ The problem of quality adjustment is common to other capital goods as well, such as new safety features for automobiles and technological improvements for major appliances.
} 


\section{Price-Index Construction}

For purposes of illustrating how to construct an index, consider this simplified example: Suppose that only two

hotels-the Alpha and the Beta-sold in 1988 , then again in 1989, and again in 1990, as shown here:

\begin{tabular}{|c|c|c|c|}
\hline & 1988 & 1989 & 1990 \\
\hline $\begin{array}{l}\text { ALPHA HOTEL } \\
\text { Sale price } \\
\text { No. of rooms }\end{array}$ & $\begin{array}{r}\$ 5 \mathrm{~m} \\
50\end{array}$ & $\begin{array}{r}\$ 6 \mathrm{~m} \\
52^{*}\end{array}$ & $\$ 5$ \\
\hline
\end{tabular}

Price per

room $\$ 100,000 \$ 115,385 \$ 105,769$

Beta Hotel

$\begin{array}{lrrr}\begin{array}{l}\text { Sale price } \\ \text { No. of rooms }\end{array} & \$ 8 \mathrm{~m} & \$ 12 \mathrm{~m} & \$ 11 \mathrm{~m} \\ \text { Price per } & & 65 & 63^{\star}\end{array}$

room $\$ 123,077 \$ 184,615 \$ 174,603$

\section{* The Alpha Hotel divided two existing suites into four rooms; the Beta Hotel created a health club out of two existing rooms.}

Note that the number of rooms in both properties changed between 1988 and 1990. The first step in the development of a simple price index for 19881990 is to calculate the "price relatives" (PR) for both properties, as shown below. A price relative is the price in the current year divided by the price in the base year (in this example, 1988).

The Alpha Hotel

$$
\begin{aligned}
& P_{88}=\left(P_{88} / P_{88}\right)=(\$ 5 m / \$ 5 m)=1.00 \\
& P_{89}=\left(P_{88} / P_{88}\right)=(\$ 6 m / \$ 5 m)=1.20 \\
& P_{90}=\left(P_{90} / P_{88}\right)=(\$ 5.5 m / \$ 5 m)=1.10
\end{aligned}
$$

The Beta Hotel

$P R_{88,89,90}=1.00,1.50,1.38$

A price index may be derived from either the arithmetic or geometric means of the hotels' price relatives, as shown:

$\begin{array}{ccc} & \text { Arithmetic Mean } & \text { Geometric Mean } \\ I_{88} & 1.00 & 1.00 \\ \mathrm{I}_{89} & 1.35 & 1.34 \\ \mathrm{I}_{90} & 1.24 & 1.23\end{array}$

\section{Price-Performance Measurement}

Changes in the prices of lodging real estate and other incomeproducing real estate usually are measured without explicit adjustments for differences in quantity, quality, and the composition of property transactions over time because such adjustments are difficult to make unless an extraor-
Because the number of rooms in the two properties are different, and the numbers of rooms changed over the course of the three-year period, the price relatives may be quantity-weighted using the number of rooms as the weights. A simple approach is to produce a weighted average of the price relatives, albeit Laspeyres in 1864 and Paasche in 1874 developed baseweighted and current-weighted indexes that are more widely accepted. The forms of the Laspeyres and Paasche indexes and the computations' results are as follows:

\section{- Laspeyres base-weighted index:$$
\mathrm{I}=\Sigma\left[\left(\mathrm{P}_{\mathrm{t}}\right)\left(\mathrm{Q}_{\mathrm{o}}\right)\right] \div \Sigma\left[\left(\mathrm{P}_{\mathrm{o}}\right)\left(\mathrm{Q}_{\mathrm{o}}\right)\right]
$$

where $P_{\text {, }}$ is the sale price in the current year, $P_{0}$ is the sale price in the base year, and $Q_{0}$ is the number of rooms in the base year.

The results are:

$\mathrm{I}_{88}=1.00 ; \mathrm{I}_{89}=1.4026 ;$ and $\mathrm{I}_{90}=1.2857$.

- Paasche current-weighted index:

$$
I=\Sigma\left[\left(P_{i}\right)\left(Q_{\mathrm{Q}}\right] \div \Sigma\left[\left(P_{\mathrm{o}}\right)\left(\mathrm{Q}_{\mathrm{f}}\right)\right]\right.
$$

where $Q_{1}$ is the number of rooms in the current year.

The results are: $I_{88}=1.00 ; I_{89}=1.4000 ;$ and $I_{90}=1.2814$.

In an effort to resolve quantityweighting issues, Irving Fisher published the results of extensive tests on a wide variety of price indexes. ${ }^{1}$ Fisher concluded that the geometric mean of the Laspeyres and Paasche indexes is an "ideal" quantity-weighted, discretetime price index. ${ }^{2}$ The form of Fisher's index and the results for the Alpha and the Beta are shown below.

- The Fisher ideal index:

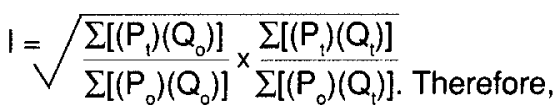
$I_{88}=1.00 ; I_{89}=1.4013 ;$ and $I_{90}=1.2836$.
Because methods such as the three just presented can't account for all the differences in characteristics of the individual items sold (e.g., quality changes, composition of sales), it's valuable to have statistical models that can: these are known as hedonic pricing models.

Hedonic price indexes. Hedonic price indexes are constructed from the statistically estimated parameters of price models. These hedonic models are conceptually based on the premise that durable goods are composites of separately measurable characteristics. The characteristics are represented as variables in hedonic models. For example, the variables used to form indexes of automobile prices measure the contributions of horsepower, weight, and vehicle length. ${ }^{3}$ Some of the measurable characteristics in single-familyhouse price models are the age of the structure, square feet of living area, number of bedrooms, presence of a swimming pool, proximity to shopping, and perceived quality of the neighborhood. $^{4}$

Hedonic pricing models have the following general form: $P=B_{i}+\left[\left(B_{1}\right)\left(X_{1}\right)\right]+\left[\left(B_{2}\right)\left(X_{2}\right)\right] \ldots\left[\left(B_{n}\right)\left(X_{n}\right)\right]+u$ where $P$ is the price of the good, $X_{t}, X_{2} \ldots X_{n}$ are variables representing separately measurable characteristics of the composite good, $B_{i}, B_{1}, B_{2} \quad B_{n}$ are the intercept term $\left(\beta_{i}\right)$ and other parameters (i.e., coefficients) associated with each variable, and $u$ is the random error term. The parameters may be estimated by ordinary least-squares procedures, also commonly known as multipleregression analysis, or with moreadvanced econometric procedures.

Implicit prices. The parameters of hedonic pricing models are referred to as implicit prices. Because each parameter (except $\beta_{i}$ ) represents a single variable's effect on the price of the good, they are the corresponding implicit prices of the separately measured dinary amount of information is available about every transaction. The National Real Estate Index, ${ }^{4}$ for example, reports quarterly price changes for office, retail, warehouse, and apartment properties in various local markets as statistical averages (weighted) of transaction

'The National Real Estate Index is produced with the joint sponsorship of Standard and Poor's, Ernst and Young, and Liquidity Fund. prices. Achieving this breadth of reporting on a price-adjusted basis would be a formidable accomplishment.

For other indexes of real-estate performance, such as the RussellNational Council of Real Estate Investment Fiduciaries Property Index, changes in prices are approximated by changes in the appraised values of a constant 
characteristics. The term "implicit prices" is appropriate because variable characteristics (such as horsepower in automobiles and living space in houses) are not traded in their own markets independently of the other characteristics of the item for sale. Thus, price indexes derived from hedonic pricing models are actually indexes of the estimated implicit prices of goods evaluated at specified quantities for each characteristic, usually the median level.

Correspondingly, the Fisher Ideal Price Index takes the form:

$I=\sqrt{\frac{\sum\left[\left(B_{t}\right)\left(X_{0}\right)\right]}{\sum\left[\left(B_{0}\right)\left(X_{0}\right)\right]} \times \frac{\sum\left[\left(B_{t}\right)\left(X_{t}\right)\right]}{\sum\left[\left(B_{0}\right)\left(X_{t}\right)\right]}}$

where $B_{0}$ represents the implicit prices estimated in the base period,

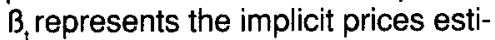
mated in the current period, $X_{0}$ represents the median quantities of the characteristics in the base period, and $X$ represents the median quantities of the characteristics in the current period.

The index of hotel and motel price movements presented here is developed from a large data base of property transactions using the last two equations described above (i.e., the hedonic pricing model and the Fisher Ideal Price Index).-J.B.C. and J.A.D.

'Irving Fisher, The Making of Index Numbers (Boston: Houghton Mifflin Co., 1922).

${ }^{2}$ Another family of indexes is used for continuous-time measurement.

${ }^{3}$ One of the first studies of this type is by Zvi Griliches, "Hedonic Price Indexes for Automobiles: An Economelric Analysis of Quality

Changes," in Price Indexes and Quality Changes, ed. Zvi Griliches (Cambridge, MA: Harvard University Press, 1971), pp. 55-87.

${ }^{4} \mathrm{~A}$ vast literature exists on applications of hedonic pricing models in real estate. Two recent publications are Fredrich G. Schuler, "Econometric Analysis of Housing Prices," Real Estate Appraiser and Analyst, Fall 1990, pp. 20-32; and Billie Ann Brotman, "Linear and Nonlinear Appraisal Models," Appraisal Journal, April 1990 , pp. 249-253.

sample of properties. ${ }^{5}$ Keeping the sample of properties constant controls for quality over time and avoids the problem of changes in the property-sample composition, but appraised values may not accurately represent supply-and-

\footnotetext{
'l'he index tracks the total return (income and appreciation) of nearly 1,200 properties across the U.S. It is produced by Russell Analytical Services, 909 A Street, Tacoma, WA 98402.
}

\begin{tabular}{|c|c|c|c|c|c|}
\hline \multicolumn{6}{|c|}{$\begin{array}{l}\text { EXHIBIT } 1 \\
\text { Property price trends and hotel valuation index }\end{array}$} \\
\hline Year & $\begin{array}{l}\text { Average Price } \\
\text { per Room of } \\
\text { Hotels \& Motels }\end{array}$ & $\begin{array}{l}\text { Percent } \\
\text { Change }\end{array}$ & $\begin{array}{c}\text { Number } \\
\text { of } \\
\text { Sales }\end{array}$ & $\begin{array}{l}\text { Hotel } \\
\text { Valuation } \\
\text { Index }\end{array}$ & $\begin{array}{l}\text { Change in } \\
\text { the Index }\end{array}$ \\
\hline 1975 & $\$ 23,850$ & & 14 & & \\
\hline 1976 & 21,829 & -8.5 & 23 & & \\
\hline 1977 & 15,387 & -29.5 & 44 & & \\
\hline 1978 & 23,642 & 53.6 & 89 & & \\
\hline 1979 & 32,633 & 38.0 & 151 & & \\
\hline 1980 & 34,480 & 5.7 & 211 & & \\
\hline 1981 & 34,457 & -0.1 & 313 & & \\
\hline 1982 & 38,264 & 11.1 & 373 & & \\
\hline 1983 & 47,723 & 24.7 & 451 & & \\
\hline 1984 & 55,031 & 15.3 & 471 & & \\
\hline 1985 & 56,500 & 2.7 & 531 & & \\
\hline 1986 & 64,340 & 13.9 & 621 & 1.0000 & \\
\hline 1987 & 81,141 & 26.1 & 356 & .9464 & -5.4 \\
\hline 1988 & 86,794 & 7.0 & 445 & 1.0536 & 10.7 \\
\hline 1989 & 75,928 & -12.5 & 360 & 1.1250 & 7.1 \\
\hline 1990 & $79,390^{\star}$ & $4.6^{\star}$ & $79^{\star}$ & 1.0714 & -5.0 \\
\hline \multicolumn{6}{|c|}{$\begin{array}{l}\text { Source: The Hotel Valuation Journal and the Hospitality Market Data Exchange, } \\
\text { Hospitality Valuation Services, } 372 \text { Willis Avenue, Mineola, New York } 11501 .\end{array}$} \\
\hline \multicolumn{6}{|c|}{ * Based on preliminary data that were available at the time we went to press. } \\
\hline
\end{tabular}

demand conditions that transaction prices are able to capture. $^{6}$

Price data provide lodgingproperty owners, lenders, and managers with benchmarks for tracking values. Hospitality Valuation Services (HVS) annually reports the national average price per room from transactions involving hotels and motels as the Hospitality Market Data Exchange (HMDE). The HMDE is a nonprofit clearinghouse of property sales compiled by HVS from brokers, appraisers, and other market participants. No attempt is made to index the price series (see Exhibit 1).

In 1986, HVS created the Hotel Valuation Index in association with Smith Travel Research to make a formal index of the market values of typical hotels in each of 25

${ }^{6}$ The problems of using appraised values to approximate market prices are documented in a research report by $S$. Ross and $R$. Zisler, "Managing Real Estate Portfolios, Part 3: A Close Look at Equity Real Estate Risk," Real Estate Research (Goldman Sachs), November 1987. metropolitan areas of the United States and for the nation as a whole. The market values of typical hotels are estimated by capitalizing the stabilized net operation incomes, using a capitalization rate that reflects prevailing debt and equity costs of capital. The Hotel Valuation Index for the United States is shown in Exhibit 1.

\section{Method and Data}

The principal methodological traditions for development of residential-property hedonic price indexes are the "cross-sectional" tradition and "time-series" tradition. In the cross-sectional tradition, the contributions of property characteristics are estimated with separate multiple regression equations for each period. The price index is created following the procedures described in the box on page 72 . Only one regression equation is estimated in the time-series tradition, in which the data for all periods are pooled and a time 


\section{EXHIBIT 3}

\section{Variables in the data base}

\begin{tabular}{|c|c|}
\hline Variable & Description \\
\hline CEP & Selling price adjusted for extraordinary financing \\
\hline RATE & $\begin{array}{l}\text { Either the average room rate or published single occupancy rate at } \\
\text { time of sale }\end{array}$ \\
\hline ROOM & The number of rooms at time of sale \\
\hline AGE & Age in years at time of sale \\
\hline $\begin{array}{l}\text { BUY, } \\
\text { SEL }\end{array}$ & $\begin{array}{l}\text { Ownership form of buyers and sellers including individuals, partner- } \\
\text { ships, domestic real estate corporation, domestic hotel corporation, } \\
\text { foreign corporation, domestic institution, and foreign institution }\end{array}$ \\
\hline CHAN & Affiliation with major hotel or motel chain \\
\hline CAS & Properties with casino gambling \\
\hline CON & Properties with major conference center or convention facilities \\
\hline SUIT & All suites lodging facility \\
\hline LTD & $\begin{array}{l}\text { Limited service lodging facility. Defined as motels or motor hotels } \\
\text { without food and beverage service }\end{array}$ \\
\hline GOLF & Properties with golf as an amenity \\
\hline TEN & Properties with tennis as an amenity \\
\hline POOL & Properties with one or more pools \\
\hline REST & Properties with one or more food and beverage operations \\
\hline DAIR & Distance in miles between properties and the nearest airport \\
\hline DCOM & Distance in miles between properties and nearest convention center \\
\hline EMP & Number of employed persons in the county during the month of sale \\
\hline & Change in EMP (annual rate) \\
\hline UNEM & Unemployment rate in the county during the month of sale \\
\hline CDI & $\begin{array}{l}\text { Effective buying income per capita in the county during the year of } \\
\text { sale }\end{array}$ \\
\hline
\end{tabular}

variable is introduced into the model. The model is then simulated for each period under study using the median values for the characteristics multiplied by their respective parameters, including each time-specific parameter.

The merits of these alternative approaches have been debated withoul firm conclusions emerging about the superiority of one method over the other. The timeseries approach provides for more straightforward statistical interpretations of the significance of changes in prices over time, but is not well-integrated theoretically into price-index literature. Problems of parameter instability and the massive data requirements associated with the cross-sectional method usually render the approach useless for real-estate price-index work. ${ }^{7}$ We adopted the time-series approach because it allows for estimation of quarterly price indexes. The data base described below is too small to estimate quarterly price indexes using the cross-sectional approach.

Income-property prices. Studies that adopt hedonic pricing techniques to analyze incomeproperty markets have been limited in number because of the enormous time and expense involved in acquiring propertylevel data. Few studies have sought to explain variation in property transaction prices. ${ }^{8}$ Most have been concerned with explaining variation in either apartment

'For a lengthier discussion of these issues and a literature review through 1981, see: B.B. Bryan and P.F. Colwell, "Housing Price Indexes," in Research in Real Estate, ed. C.F. Sirmans (Greenwich, Connecticut: JAI Press, 1982), pp. 57-84.

"The only complete study is J.W. Hoag, "Toward Indices of Real Estate Value and Return," Journal of Finance, 35, No. 2 (May 1980), pp. 569-580. rental rates, apartment operating expenses, office rental rates, or hotel room rates. ${ }^{9}$ This is the first study to index income-property prices using the hedonic pricing method.

The lodging-property transaction data assembled to construct. our price index satisfy the following general specifications:

(1) The data are limited to hotels and motels. A property is defined as a hotel if it includes 150 rooms, meeting and banquet space, and restaurant facilities.

(2) The data are national in scope. Any geographical breakdown would not yield a sufficient number of usable observations.

(3) The data are detailed with respect to property characteristics, location, and local economic conditions at the time of sale. Certain contractual characteristics endemic to the sales are also included.

(4) The study period is the first quarter of 1985 through the last quarter of 1990.

The primary source of transaction information is the data base of the HMDE. The HMDE contains the sale price, number of rooms, date of sale, and general-location information for several thousand properties. Additional information about the characteristics of the properties, such as average room

${ }^{9}$ For a study of apartment-rental rates, see: K.L. Gunterman and S. Norrbin, "Explaining the Variability in Apartment Rents," AREUEA Journal, 15, No. 4 (Winter 1987), pp. 321-340; for a study of apartment operating expenses, see: S.B. Rosenberg and J.B. Corgel, "Agency Costs in Apartment Property Management Contracts," AREUEA Journal, 18, No. 2 (Summer 1990), pp. 184-201; for a study of office-rental rates, see: T.P. Brennan, R.E. Cannady, and P.F. Colwell, "Office Rent in the Chicago CBD," AREUEA Journal, 12, No. 3 (Fall 1984), pp. 243-260; and for a study of hotel room rates, see: S.A. Carvell and W.E. Herrin, "Pricing in the Hospitality Industry: An Implicit Markets Approach," FIU Hospitality Revieu, 8, No. 2 (Fall 1990), pp. 27-37, and R.S. IIartman, "Iedonic Methods for Evaluating Product Design and Pricing Strategies," Journal of Economic's and Business, 41, No. 3 (August 1989), pp. 197-212. 
rate, age, amenities, and the conditions of the sales-financing terms and the organization forms of buyers and sellers, for example-were obtained during visits to the HVS office. Other data were gathered from the following sources:

(1) Hotel \& Travel Index, the AH\&MA's Hotel and Motel Redbook, and Mobil Travel Guides;

(2) Members of the Hotel and Motel Brokers Association;

(3) Telephone interviews with hotel and motel managers;

(4) Bureau of Labor Statistics and U.S. Bureau of the Census; and

(5) Sales and Marketing Management magazine.

More than 900 transactions are in the data base. Although the hotel and motel subsamples are not randomly chosen, efforts were made to avoid concentrations of property sales by quarter, geographic region, chain affiliation, and other property characteristics. Exhibit 3 shows the key variables included in the hedonic pricing model.

\section{Cornell Lodging Property Index}

Exhibit 4 presents the index numbers for our overall lodgingproperty price index, which includes hotels and motels, and for separate indexes of hotel and motel property prices. The indexes are quarterly, extending from 85-1 (first quarter of 1985) through 90-4 (last quarter of 1990), and the base period is 85-1 (100). For comparison purposes, Exhibit 4 also shows the quarterly price relatives of median hotel and motel prices from the HMDE.

The lodging-property index reveals that prices remained flat through mid-1986, rose sharply during the last two quarters of 1986, and experienced a steady

\section{EXHIBIT 4}

Cornell Lodging-Property Index

\begin{tabular}{|c|c|c|c|c|}
\hline $\begin{array}{c}\text { Year } \\
\text { (quarterly) }\end{array}$ & $\begin{array}{c}\text { HMDE } \\
\text { Median Price } \\
\text { Relatives }\end{array}$ & $\begin{array}{l}\text { Lodging- } \\
\text { Property } \\
\text { Index* }^{*}\end{array}$ & $\begin{array}{l}\text { Hotel } \\
\text { Index }\end{array}$ & $\begin{array}{l}\text { Motel } \\
\text { Index }\end{array}$ \\
\hline 1985-1 & 100.0 & 100.0 & 100.0 & 100.0 \\
\hline $1985-2$ & 86.0 & 92.3 & 98.1 & 79.5 \\
\hline $1985-3$ & 91.0 & 97.0 & 121.6 & 78.2 \\
\hline $1985-4$ & 125.0 & 93.6 & 104.4 & 75.6 \\
\hline $1986-1$ & 85.0 & 91.1 & 94.0 & 94.5 \\
\hline $1986-2$ & 92.0 & 97.7 & 110.8 & 90.5 \\
\hline $1986-3$ & 99.0 & 122.9 & 135.8 & 102.0 \\
\hline $1986-4$ & 130.0 & 102.3 & 95.9 & 104.5 \\
\hline $1987-1$ & 74.0 & 87.1 & 89.1 & 84.4 \\
\hline $1987-2$ & 109.0 & 82.8 & 90.7 & 75.9 \\
\hline $1987-3$ & 94.0 & 83.8 & 107.7 & 73.5 \\
\hline $1987-4$ & 110.0 & 63.8 & 68.3 & 73.1 \\
\hline $1988-1$ & 112.0 & 89.1 & 106.2 & 81.4 \\
\hline $1988-2$ & 89.0 & 70.8 & 82.5 & 71.6 \\
\hline $1988-3$ & 118.0 & 72.6 & 69.9 & 79.3 \\
\hline $1988-4$ & 85.0 & 78.9 & 76.1 & 91.3 \\
\hline $1989-1$ & 79.0 & 69.1 & 63.4 & 76.0 \\
\hline $1989-2$ & 77.0 & 74.5 & 78.6 & 71.6 \\
\hline $1989-3$ & 67.0 & 71.9 & 72.1 & 73.8 \\
\hline $1989-4$ & 90.0 & 71.7 & 80.4 & 67.3 \\
\hline $1990-1$ & 124.0 & 77.1 & 80.8 & 71.5 \\
\hline $1990-2$ & 106.0 & 78.9 & 74.4 & 86.6 \\
\hline $1990-3$ & 100.0 & 65.1 & 50.4 & 68.1 \\
\hline $1990-4$ & $\begin{array}{c}\text { Not } \\
\text { available }\end{array}$ & 69.4 & 75.9 & 69.8 \\
\hline \multicolumn{5}{|c|}{ *Includes both hotels and motels } \\
\hline
\end{tabular}

decline throughout the remainder of the 1980 s and into the 1990 s. The sharp rise in prices in late 1986 is related to the real-estate trading that occurred just prior to the tax-law changes. Absent is any indication of general market movement due to the buying spree of Japanese investors during 1987 and 1988. By the end of 1990 , prices of lodging properties were 70 to 75 percent of their 1985 levels.

The HMDE median-price relatives are shown to compare the hedonic index to an unadjusted price series (Exhibit 4). One would expect the HMDE's price relatives to perform differently, compared to the hedonic price index, because of the adjustments made by the hedonic equation. The pattern of the hedonic price index is quite different from the pattern exhibited by the HMDE price relatives (Exhibit 4). The difference in mean values of the index numbers and price relatives is statistically significant at the .05 level and the correlation coefficient ( $r$ ) is only .27. In addition, the HMDE price relatives are far more volatile than the lodging-property index. This is graphically demonstrated in Exhibit 5. Finally, the index is generally lower than the HMDE price relatives.

\section{Hotel Prices versus Motel Prices}

The index numbers in Exhibit 4 and the graphic representation of those numbers in Exhibit 6 indicate a slightly different pattern of price movement of hotel-property sales when compared to motel properties during the period 1985-1990. Neither price index is highly correlated 


\section{EXHIBIT 5}

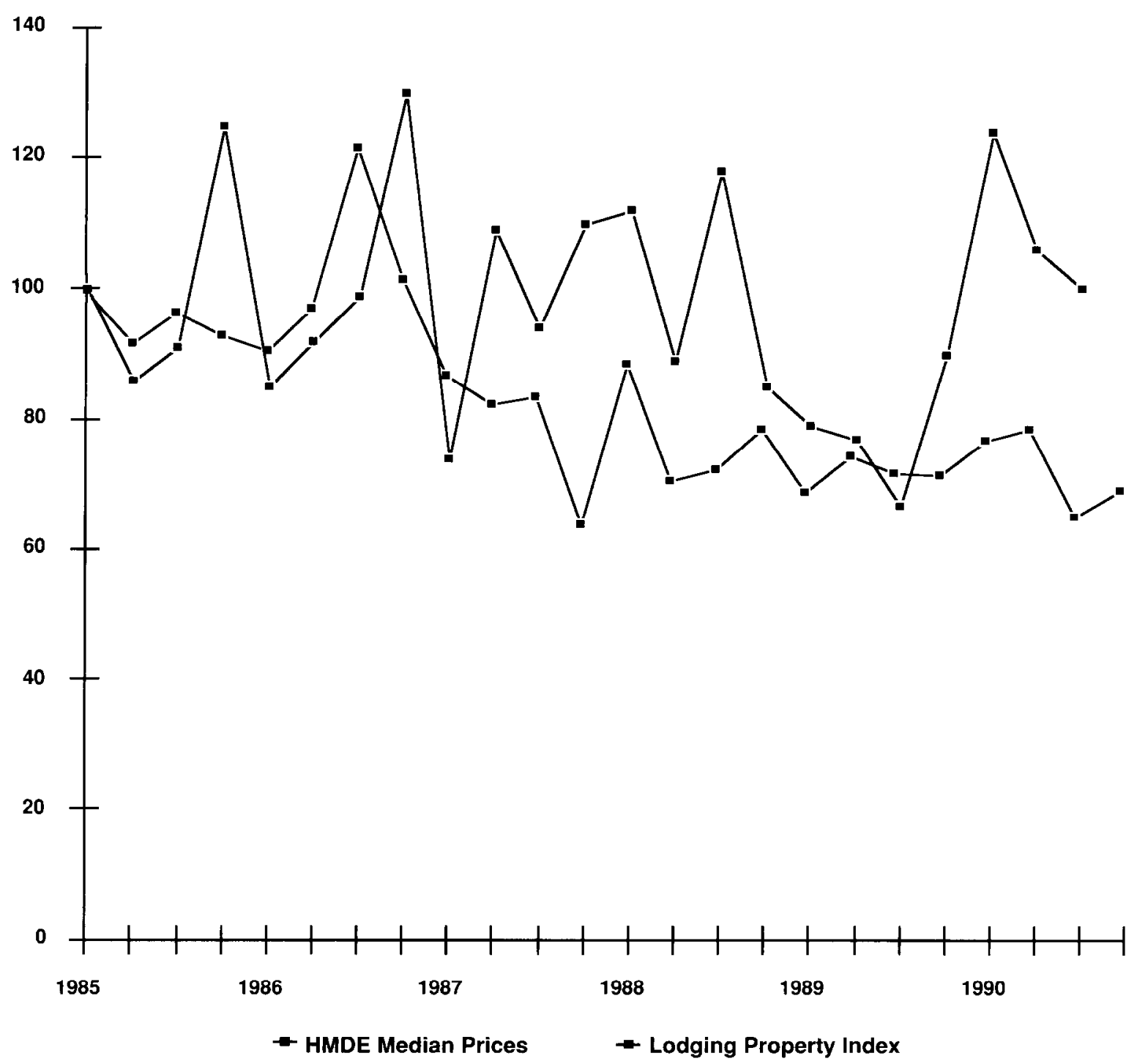

with the HMDE price relatives $(\mathrm{r}=.22, .24)$ although the .44 correlation coefficient between the hotel and motel indexes is statistically significant.

Despite the statistical significance, Exhibit 6 shows that during several quarters the two indexes move in opposite directions.

Generally, hotel-property prices held up better than motel-property prices during the real-estatemarket collapse of the late 1980s.
Overall, the hotel and motel indexes were less volatile and more convergent during the last three years of the study period than the data show for the earlier periods of 1985-1987.

Finally, the history of HVS's Hotel Valuation Index is not sufficiently long to draw a statistical comparison with the price index. In any event, such a comparison may not be meaningful because of the difference in definitions between market value and market price in the realestate appraisal literature. ${ }^{10}$

\section{Useful Comparisons}

The prices of lodging properties are of interest and concern to many professionals including corporate execulives, mortgage lenders, real-estate appraisers,

10See: The Appraisal of Real Estate (Chicago: American Institute of Real Estate Appraisers, 1987), Chapter 2, pp. 15-30. 


\section{EXHIBIT 6}

\section{Cornell Lodging-Property Index-comparison between hotels and motels}

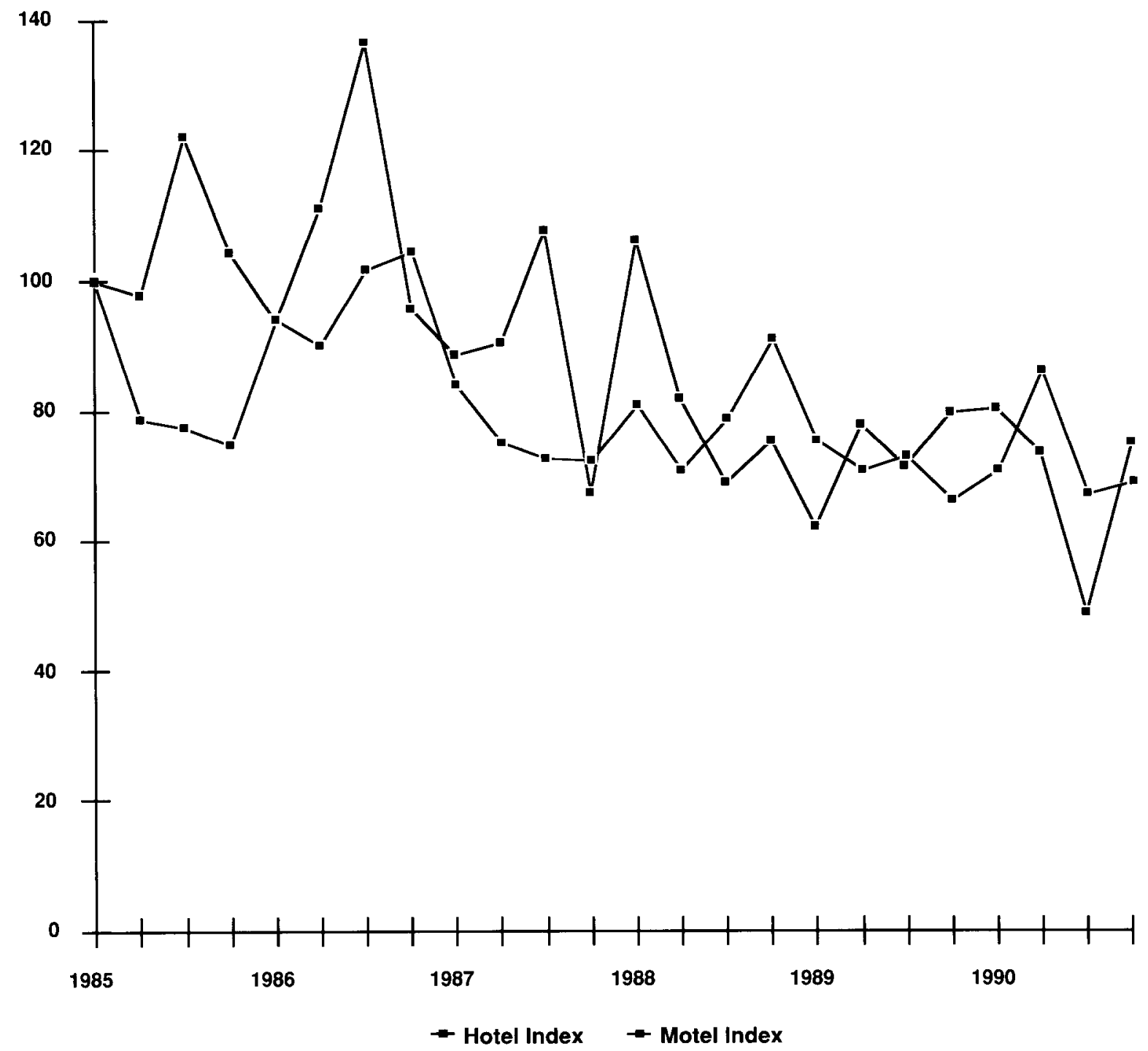

hotel and motel property investors, and even academic researchers. To gain a clear picture of the pattern of price movement in the market, the "raw" selling prices of properties must be screened for abnormalities (e.g., less than arms-length transactions), corrected for extraordinary financing, and properly indexed. The indexing procedures used to develop the Cornell Lodging Property Indexes were designed to reveal price movements without the influences of quantity, quality, and sample-composition differences among properties and over time.

The indexes show a precipitous decline in prices following the Tax Reform Act of 1986. This decline has been exacerbated by weakness on the demand side and was not halted or reversed by the dramatic entrance of Japanese investors beginning in 1987 . (Those Japanese investors, who tended to purchase high-priced trophy properties, represented a relatively small number of transactions among all lodging-property sales. Therefore, the high prices paid by the Japanese for those premium properties did not contaminate the market data, generally.) The index numbers also show that prices were flat between late 1988 and the end of 1990 , perhaps an indication that the property market bottomed in late 1988. co 